\title{
KOMUNIKASI OMBUDSMAN DALAM SOSIALISASI ADUAN PUBLIC SEBAGAI LEMBAGA PENGAWASAN PUBLIC DI PROVINSI RIAU
}

\author{
Sudianto \\ Dosen Jurusan Ilmu Komunikasi, Fakultas Dakwah dan Komunikasi,UIN Suska Riau, \\ Jl. HR Soebrantas Km 15 Simpangbaru, Tampan, Pekanbaru 50275
}

\begin{abstract}
Abstrak
Komunikasi yang dilakukan oleh lembaga Ombudsman adalah komunikasi melalui sosialisasi untuk memberikan pengawasan dengan mensosialisasikan edukasi pelayanan public yang baik, bagi lembaga pemerintah tingkat kabupaten dan kota di provinsi Riau. Dengan memberikan arahan pelayanan yang prima kepada masyarakat.. Mengajak dan membangun hubungan kerja sama guna terciptanya iklim birokrasi yang transparan. Kemudian terbangunnya pola komunikasi yang dinamis pada pelayanan public.Model komunikasi Ombudsman adalah suatu pola yang cukup menarik perhatian dalam meningkatkan koordinasi bagi tiap lembaga pemerintah. Dalam hal ini ada dua pola komunikasi yang dapat dijadikan sebagai bentuk komunikasi ombudsman pada lembaga pemerintah diantaranya; penyelidikan lapangan dan pencegahan.yakni penyelidikan lapangan dengan melakukan koordinasi dengan satuan kerja pada dinas terkait ketika ada laporan dari masyarakat mengenai pelayanan yang kurang baik, kemudian dievalusi kinerja lembaga tersebut. Kemudian ada tahap pencegahan ketika terjadi pelanggaran pada dinas terkait bagaimana agar dapat dievalusai kinerjanya. Kemudian dapat melakukan klarifikasi perbaikan.Sebagai komunikator Ombudsman sebagai lembaga mitra dari pemerintah dapat memberikan koordinasi dengan melakukan sosialisasi terhadapa pelayanan yang diberikan kepada public agar lebih baik dan transparan kepada masyarakat. untuk membangun komunikasi komunikasi ombudsman. Dari hasil komunikasi Ombudsman dapat memberikan pemahaman kepada public dengan mensosialisasikan kepada khalayak atau masyakat sebagai lembaga resmi yang mampu melakukan mediasi pelayanan public yang baik pada lembaga pemerintah.
\end{abstract}

Kata kunci: Komunikasi, Ombudsman, Sosialisasi, Pengawasan Public. 


\section{A. PENDAhuluan}

Ombusmen merupakan suatu badan indenpenden yang ditunjuk oleh Pemerintah yang tugasnya adalah mengawasi pengaduan public. untuk itu semua peraturan yang ada dapat di pahami oleh masyarakat. Sedangkan yang menjadi undang-undang republik Indonesia nomor 37 tahun 2008 tentang ombudsman Republic Indonesia dan Nomor 25 tahun 2009 tentang pelayanan public. Lahirnya pemikiran bahwa trasafaransi public banyak tidak berjalan sesuai dengan aturan yang ditetapkan oleh pembuat kebijakan dinegara ini. Namun sebenarnya aturan itu harus sosialisasi dan dapat dipahami sebagai ketentuan undang-undang

Setiap satuan kerja harus dapat memberikan pelayanan yang baik dalam terhadap masyarakat, tugas satuan kerja sebagai jajaran yang ada pada lembaga pemerintaah ombudsman selalu memberikan pengwasan dalam pelaksanaan yang belum maksimal serta adanya pengaduan dari masyarakat.

Sebagai amanat uu no 25 tahun 2009 ini jelas bersemangat pro rakyat standarstandar pelayanan public dijelaskan dan wajib dipenuhi oleh lembaga pelayanan public. Ombudsman Republic indonesia menerjemahkan semangat pro rakyat ini dengan mengawasi lembaga-lembaga yang menggunakan APBN itu. Ombudsman sebagai anak kandung reformasi, menjadi pendamping rakyat dalam mengawal kepatuhan lembaga pelayanan public dalam memenuhi standar pelayananan.

Sebagai wadah pengaduan public ombudsman selalu mengapresiasi atas praktik pelayanan public. Setiap pengaduan yang masuk akan direspon dengan kualifikasi pencegahan agar tidak terjadi pelanggaran.

Komunikasi merupakan proses symbol yang dapat memberikan pemamahaman kepada sesama, muncul nya mist persepsi atau pertentangan dalam Komunikasi karena terjadi nya tumpang tindih dalam pengambilan kebijakan pesan. Ombusmen sebagai lembaga indenpenden posisinya tetap mengawasi bagai mana transafaransi public semakin terbuka, sebenarnya ada suatu perinsip budaya yang dapat memehami suatu aturan terhadap system yang ada di Indonesia yaitu selalu menghargai system demokrasi sesuai dengan konsep kenegaraan. (Richard dan Lynn H., 2008:67)

Peran komunikasi sangat penting bagi manusia dalam kehidupan, sesuai dengan fungsi komunikasi yang bersifat persuasif, edukatif, dan informatif. Sebab tanpa komunikasi maka tidak adanya proses interaksi; saling tukar pengetahuan, pengalaman, pendidikan, persuasi, informasi, dan sebagainya. Proses penyampaian informasi atau pesan tersebut pada umumnya melalui suatu media komunikasi.(Ruslan,2006:82)

Bahwa konsep keterbukaan lembaga merupakan sebagai fitur penting dalam memaknai kebijakan didefinisikan sebagai pengaruh, kekuasaan, atau dominasi,dari sebuah kelompok social terhadap yang lainnya. Intinya pengkajian budaya mengingatkan kapada public menerima informasi dalam jumlah besar dari kaum elite bahwa orang secara tidak sadar menaati pesan yang disampaikan oleh ideology dominan.

Muncul dinamika ditengah masyarakat, ombusmen sebagai mitra yang harus bekerja sama untuk menerapkan aturan administarasi public yang benar . muncul gejala ditengah masyaarakat ada kebijakan yang tidak sesuai.dengan aturam main yang dibuat oleh pemerintah maka jangan heran ketika melihat sutu kasus -kasus pejabat pemerintah tidak pernah atau sangat sulit untuk diselesaikan.moralitas akan menanamkan mana yang benar dan harus 
dilaksanakan.”Moralitas juga menumbuhkan orang bersikap sportif. Artinya, mau mengakui kesalahan dirinya sendiri dan disisi lain untuk menghargai pihal lain. (Nurudin:2002:115).

Proses komunikasi adalah
mengoperasionalisasikan unsur-unsur yang menunjang komunikasi yang efektif melaksanakan peran yang dimaksud dalam komunikasi; komunikator, komunikan, pesan, media, hambatan dan kontek. dijelaskan juga oleh miller" dalam ilmu komunikasi disebut sebagai paradigma The postulat of Interpersonal need atau audience baced approach. Postulat ini juga "mengalahkan" model tradisional dalam komunikasi yang lebih mementingkan komunikator dari pada komunikan.( Liliweri:97:280 )

Manajemen program sebagai sistem yang memiliki tanggung jawab terhadap pelayanan administrasi untuk pelayanan public, harus mampu mengantarkan hasilhasil program secara efektif. Dan hal ini berhubungan dengan perlakuan (exercise) dari tangging jawab langsung bagi prodok akhir organisasi.( pentingnya program public dan kejelasan (visibility) tingginya serta nilai public bearti bahwa manajemen yang diansut oleh pemimpin politik dan mamajer profesional. Peran manajemen kunci dalam kepemimpinan politik selalu mendesak dalam pengawasan adalah interprestasi kebutuhan public. Diantara program pelayanan public sasaran (goals) dan tujuan (objectives).(Tangkilisan,2003:102)

Ruang lingkup pelayanan umum yang diberikan oleh aparatur pemerintah meliputi : melayani, mengayomi dan menumbuhkan prakarsa serta peran aktif masyarakat dalam pembangunan. Pelayanan public sangat terkait dengan profesionalitas dan moral aparatur yang sangat signifikan ditentukan oleh faktor pendidikan, pengalaman, dan keahlian. Selain itu berkitan dengan profesi, memerlukan keahlian tertentu. Begitu juga dengan akuntabilitas, bahwa pelayanan public menghendaki setiap kegiatan aparatur dapat dipertanggung jawabkan kepada public sebagai pemegang kedaulatan tertinggi. ( Walid, 2008:87)

Joseph T.Klapper "Mengatakan suatu kelompok sering ditandai dengan pandanganpandangan tertentu, dan sering menjadi sumber serta mengarahkan pandangan individu, lewat komunikasi formal dan informal, kelompok-kelompok ini berfungsi sebagai mediator bagi pembentukan pengaruh komunikasi massa atas anggota-anggotanya. (Mulyana: 1999:93)

Pemeliharaan hubungan dengan bawahan yang dilakukan oleh atasan memerlukan komunikasi yang efektif. Komunikasi merupakan keharusan yang harus dilakukan oleh setiap lembaga yang menyangkut organisasi disampaikan dari satu pihak kepihak lain.terdapat empat arus komunikasi, pertama: komunikasi vertikal kebawah. Komunikasi demikian merupakan komunikasi dari pimpinan kepada bawahannya, seperti perintah, intruksi, kebijaksanaan baru, pengarahan, pedoman kerja, nasehat dan teguran.

Kedua; Komunikasi vertikal keatas. para anggota organisasi selalu ingin didengar oleh para atasannya, seperti; laporan hasil pekerjaan, masalah yang dihadapi, baik yang sifatnya kedinasan, maupun yang sifatnya pribadi, saran-saran yang menyangkut pelaksanaan tugas masing-masing dan bahkan juga kritik dalam membangun organisasi. Ketiga; Komunikasi horizontal; komunikasi berlangsung antara orang-orang yang berada pada tingkat yang sama dalam hirarki organisasi akan tetapi melaksanakan kegiatan yang berbeda-beda. Keempat; Komunikasi diagonal, komunikasi ini berlangsung antara dua satuan kerja yang berada pada jenjang hierarki organisasi yang berbeda, tetapi 
menyelenggarakan kegiatan yang sejenis. Sondang,2008:307)

Sebagai sasaran untuk mencapai tujuan harus orisinal dan baru, atau evaluasi terhadap kebijakan sebelumnya. Barangkali suatu tujuan, siap diterima atau menuntut persesuaian yang luas serta membutuhkan sosialisasi yang edukasi guna mengkomunikasikan tujuan apa yang diharapkan. Namun boleh jadi tujuan tersebut hanya didukung setengah-setengah. Tetapi, sasaran itu dapat meledakkan pertentangan intern. Beberapa sasaran yang dipilih, tentu saja, sasaran yang dapat menjadi kekuatan pemersatu. Sedangkan sasaran yang lain, hanya dipilih sebagai penentu umum dalam situasi yang bertentangan. Sebagai leader eksekutif harus melakukan peran yang dinamis, seperti; merivisi, atau meninjau kembali, bertinndak atau membujuk, mencegah, atau mengisi, melanjutkan atau menghentikan. ( Coulson dan Thomas,2005:75)

Peran lembaga harus mampu mengorganisir kepercayaan public,agar setiap tindakan dapat mengarahkan oreintasi kepada keberhasilan. Dalam situasi citra lembaga atau organisasi harus menggunakan format sebagai acuan dalam melakukan sasaran tindakan. Minimal mengevaluasi agar stabiltas dapat bertahan, sebagai upaya dapat dilakukan dengan beberapaa strategi komunikasi public; pertama, penggolongan posisi individu kepada kelompok. Ada yang disebut anggota internal (members group). Ada juga individu yang merupakan anggota lain, tetapi sering menjadi panutan (references group) Kedua, memilih fokus yang baru yang dapat membangkitkan nilai kemanusiaan (humanities)( Olii dan erlita,2011: 104)

Partisipasi masyarakat dalam perumusan kebijakan public, sebagai penerapan esensi demokrasi adalah terbukanya peluang partisipasi masyarakat dalam proses perumusan kebijakan public. Sistem yang ada dinegara demokratis, menyediakan ruang public yang dianggap serasi bagi masyarakat, untuk menjalankan aspek yang ada sebagai penyerap aspirasi dan kepentingannya terhadap pembuat kebijakan atau decision makers (Zuhro, 2009 :89)

\section{B. Komunikasi Ombudsman Dalam Sosialisasi Aduan Public Sebagai Lembaga Pengawasan Public Di Provinsi Riau.}

Komunikasi yang dilakukan oleh lembaga Ombudsman adalah komunikasi melalui sosialisasi untuk memberikan pengawasan dengan mensosialisasikan edukasi pelayanan public yang baik, bagi lembaga pemerintah tingkat kabupaten dan kota di provinsi Riau. Dengan memberikan arahan pelayanan yang prima kepada masyarakat.. Mengajak dan membangun hubungan kerja sama guna terciptanya iklim birokrasi yang transparan. Kemudian terbangunnya pola komunikasi yang dinamis pada pelayanan public.

Dalam komunikasi ada komponenkomponen yang harus menjalankan fungsinya diantaranya: sumber, pesan, media, penerima, pengaruh, tanggapan balik dan lingkungan (Canggara:2008:24-27)

Model komunikasi Ombudsman adalah suatu pola yang cukup menarik perhatian dalam meningkatkan koordinasi bagi tiap lembaga pemerintah. Dalam hal ini ada dua pola komunikasi yang dapat dijadikan sebagai bentuk komunikasi ombudsman pada lembaga pemerintah diantaranya; penyelidikan lapangan dan 
pencegahan.yakni penyelidikan lapangan dengan melakukan koordinasi dengan satuan kerja pada dinas terkait ketika ada laporan dari masyarakat mengenai pelayanan yang kurang baik, kemudian dievalusi kinerja lembag tersebut. Kemudian ada tahap pencegahan ketika terjadi pelanggaran pada dinas terkait bagaimana agar dapat dievalusai kinerjanya. Kemudian dapat melakukan klarifikasi perbaikan.Sebagai komunikator Ombudsman sebagai lembaga mitra dari pemerintah dapat memberikan koordinasi dengan melakukan sosialisasi terhadapa pelayanan yang diberikan kepada public agar lebih baik dan transparan kepada masyarakat. untuk membangun komunikasi komunikasi ombudsman melakukan koordinasi sebelum turun kelapangan. memberdayakan beberapa komponen yang mendukung program diantarnya:

1. Kepala Ombudsaman sebagai komunikator utama yang berperan dalam membangun pola komunikasi dakwah sesuai dengan orientasi dan tujuan yang diinginkan dalam komunikasi pelayanan public.

2. Para asisten ombudsman sebagai komunikator yang senantiasa melakukan pemantauan ditengah-tengah masyaarkat untuk tetap mengajak bahwa perlunya peningkatan pelayanan public yang baik pada setiap lembaga pemerintah dan dengan pola transparan.

3. Setiap masyarakat yang memberi aduan ombudsman selalu menerima setiap laporan untuk ditidaklanjuti. Dengan menerima laporan pada posko informasi yang di tentukan.

4. Menjadikan lembaga sosial masyarakat sebagai mediasi masyarakat ketika ada laporan. Kemudian untuk tetap selalu mensosialisasikan kepada public yang ingin memberikan aduan public.

\begin{abstract}
Selain pemberdayaan untuk menjalankan program perlu strategi komunikasi dalam membuat kebijakan diantaranya:

a. Kebijakan pada setiap satuan kerja. Memberikan pelayan yang prima kepada masyarakat demi tercapainya masyarakat yang adil dan makmur untuk memperoleh keberhasilan.

b. Kebijakan Aparatur. Melaksanakan peran aktif lembaga secara potensial, sehingga ada kesesuai antara kuantitas dan hasil secara periodik.

c. Kebijakan manajemen. Sebagai usaha yang dilakukan oleh instansi pemerintah menggerakkan personel dan menggunakan fasilitas yang ada sehingga tercapai tujuan dan sasaran sesuai dengan keinginan.

d. Kebijakan Prosedur. Menjalankan program sesuai dengan prosedur dan tata cara atau mekanisme yang berlaku.
e. Kebijakan pendayagunaan
Pendistribusian sesuai dengan kriteria yang berlaku.

\section{Pesan Komunikasi}

Dalam komunikasi pesan merupakan salah satu unsur yang meliputi proses komunikasi yang sangat berperan dalam mengubah perilaku individu sehingga dapat dicapai tujuan komunikasi yang diinginkan program peningkatan pelayan public yang baik ditengah lembaga pemerintah daerah.

Salah satu program ombudsman untuk meningkatkan pengawasan kinerja lembaga pemerintah .menjalan kan tupoksi bagi setiap satuan kerja sesuai dengan sasaran dan standar kerja. Sebagai lembaga merupakan oraganisasi pemerintah harus mengacu kepada program yang berbasis kepada potensi sehingga eksistensi lembaga organisasi dapat berjalan secara maksimal. 
Sebagai upaya untuk meningkatkan pengawasan lembaga ombudsman memberdayakan program terstruktur diantaranya :

i. Membangun jaringan komunikasi dengan lembaga sosial kemasyarakatan secara kolektif dalam menjalankan program pengawasan pelayanan public.

ii. Membangun pola komunikasi kolektif dengan asisten ombudsman untuk melakukan penyelidikan kemasyarakat berupaya menerima setiap laporan yang masuk.

iii. Mengakomodir informasi dari masyarakat ketika ada laporan kemudian dilakukan tindakan untuk dievaluasi.

$\begin{array}{rlll}\text { Dari } & \text { beberapa } & \text { tahapan } & \text { diatas } \\ \text { ombudsman } & \text { secara } & \text { continyu } & \text { selalu }\end{array}$ membangun koordinasi dengan masyarakat yang rawan dengan partisipasi pelayanan yang rendah. Untuk itu ombudsman dapat menjalankan perannya ketengah masyarakat dalam menggelola informasi dari masyarakat, kemudian hasilnya dapat ditindak lanjuti sampai ketingkat pusat.

Ombudsman sebagai lembaga pengawasan public, dapat memberikan kontribusi terhadap mutu pelayanan untuk memudahkan masyarakat dalam berurusan pada setiap lembaga pemerintah. Pelayan yang sesuai dengan aturan yang teleh ditetapkan oleh pemerintah. Pelayanan secara legal agar lembaga pemerintah lebih tertib mudah melakukan kualifikasi demi terwujudnya lembaga yang baik. (wawancara Kepala ombudsman riau).

Salah satu fungsi pengawasan yang dilakukan ombudsman Riau adanya evalusi yang dilakukan oleh kepala daerah pada setiap satuan kerja dan dinas terkait yang memiliki nilai standar prestasi kerja yang . Kepala ombudsman RI Provinsi Riau, keberadaannya mengundang perhatian ketika mendengar ada laporan Gubernur yang disebut menunjukkan prestasi kerjanya yang baik, diantaranya; Badan pelayanan perizinan terpadu (BP2T), Kepala dinas pendapatan (UPT pendapatan pekanbaru kota dan UPT pendapatan pekanbaru selatan) dan RSUD Arifin Ahmad Provinsi Riau. Saat itu lah ada perbedaan yang lain ketika apel pertama pasca idul fitri.

Kemudian setiap satuan kerja yang mendapat prestasi dengan predikat kepatuhan dari ombudsman RI yang sebelumnya diterima wakil Gubernur Riau. Penyerahan itu kemudian diserakan kepada satuan kerja yang memiliki prestasi dilingkungan kerjanya. Untuk itu dapat menginpirasi bagi setiap satuan kerja yang ada di Provinsi Riau.

Meningkatkan pelayanan kepada masyarakat merupakan tanggung jawab stiap lembaga, dan menekan agar setiap satuan kerja atau SKPD dilingkungan pemerintah provinsi Riau untuk terus memberikan pelayanan yang baik kepada masyarakat. Selain itu setiap pemerintahan harus menunjukkan kepada jajarannya untuk selalu berbenah diri dalam peningkatan layanan kepada public, seperti, fakta dilapangan dapat menunjukkan bahwa masyarakat sebagai konsumen layanan tetap merasa dampaknya.

Untuk meraih prestasi kerja yang baik tidak lah mudah, ada tahapan yang harus dilalui sebelum predikat penilaian kepatuhan diberikan dengan obyek observasi ombudsman RI yang menilainya berdasarkan fakta dilapangan. Usaha ini dapat dilakukan dengan pola pendampingan bagi SKPD yang ingin meningkatkan kualiatas pelayanan public yang baik.

Sebagai upaya peningkatan dapat dilakukan dengan pola program intervensi terfokus adalah melakukan rapat koordinasi bersama pemerintah provinsi Riau dan pemerintah kabupaten dan kota, serta melaksanakan workshop peningkatan kualitas 
pelayanan public. Agar pemahaman setiap satuan kerja memiliki konsep dan dapat diterima dengan baik oleh penyelenggara layanan.

Proses intervensi harus fokus dengan konsep berkelanjutan dan rogram pendampingan (coaching) dengan cara membangun kordinasi dengan setiap satuan kerja kemudian di observasi, terutama satuan kerja yang memiliki prestasi rendah. Kemudian ombudsman RI melakukan pemantauan (monitoring) dengan memberikan perbaikan standar pelayan evaluasi terhadap kinerjnya.

Sebagai tahapan pengawasan terhadap satuan kerja perangkat daerah, memberikan informasi kapada Ombudsman RI tentang pekerjaan yang memenuhi standar pelayanan, dengan cara meminta pendampingan dalam memiliki standar pelayanan public. Sebenarnya satuan kerja (SKPD) harus respon setiap sinyal pelayanan lapisan bawah yakni masyarakat jauh sudah memeberikan evaluasi ketika ada konflik layanan.

Oleh karena itu, SKPD harus menjadikan acuan yang dibuat oleh pemerintah Provinsi Riau, seperti pergub nomor 74 tahun 2013 tentang fasilitasi pengaduan masyarakat dilingkungan pemerintah provinsi Riau. Selain itu DPRD Provinsi Riau juga melakukan menggelar Rapat dengar pendapat (RDP) sehubungan dengan pengesahan Ranperda pelayanan public. serta melibatkan sejumlah pihak seperti ombudsman RI, dan pihak perguruan tinggi negeri dan Swasta serta rumah sakit dimintai masukan terkait ranperda pelayanan public tersebut.

\section{Media Komunikasi Ombudsman}

Sebagai media komunikasi Ombudsman memberdayakan kelembagaan yang ada seperti lembaga swadaya masyarakat (LSM), Radio setiap hari dapat merangkum liputan acara program ombudsman, sosialisasi maupun evaluasi laporan masyarakat. Untuk ombudsman mensosialisasikan programnya lembaga pada setiap lembaga pemerintah untuk mewujudkan pelayanan public. sebagai komunikataor dalam menyampaikan pesan menerima informasi dari masyarakat ketika ada pelayanan yang tidak akuntable.

Dalam rangka mensosialisasikan ombudsman Riau melaksanakan program pendampingan kepada Satuan kerja perangkat daerah (SKPD).

1. Workshop mutu layanan public

2. Pendampingan kepada SKPD yang predikat kinerjanya rendah

3. Melakukan evalusi penilaian perbaikan.

\section{E. Masyarakat sebagai komunikan pelayanan public}

Sebagai komunikan public adalah masyarakat sebagai konsumen pelayanan memberikan kontribusi sebagai penilai kinerja pemerintah. yang merespon peran ombudsman, dalam pengawasan dan terbangunnya interaksi dalam pelayanan public yang baik bagi pemerintah. Sebagai respon yang mendapat pelayanan dan terbangun perilaku masing-masing individu menuju aparatur yang baik.

Melihat perkembangan semakin pesatnya penduduk diprovinsi Riau, pemerintah harus melakukan beberapa strategi komunikasi dalam memberdayakan administrasi pemerintahan untuk kepentingan masyarakat diantaranya:

1. Membangun persepsi agar fungsi administri harus mampu memberikan pelayanan dengan baik dengan cara membangun program pengembangan fasilitas masyarakat. 
2. Memberdayakan konsultan administrasi dan mensosialisasikan program yang tertib

3. Pengembalian berkas dengan secara cepat.

\section{F. Sebagai Feed Back Dalam Komunikasi public}

Feedback dalam komunikasi public adalah efek pelayanan berpengaruh terhadap perilaku kehidupan dan dapat membngun nilai-nilai yang lebih bermakna menuju perilaku yang mandiri serta tercapainya kualitas kehidupan sosial.

Dampak pelayanan yang baik dapat menciptakan pemerintah yang bermartabat ditengah kehidupan masyarakat. Dan menjadi lebih baik dan akhirnya menjadi individu yang terlatih dengan pembianaan tersebut.

Sebagai feedback komunikasi dapat terciptanya komunikasi dua arah yang baik antara produksi pemerintah dengan konsumen pelayanan. sehingga kebutuhan menjadi antara pesan yang disampaikan komunikator kepada komunikakan terarahkan lebih baik. Sebagai penentu keberhasilan dalam suatu interaksi komunikasi yang dinamis baik secara personal maupun khalayak.

\section{G. Hambatan komunikasi Ombudsman}

Sebagai pemerintah yang berperan sebagai satuan kerja dapat meningkatkan usaha pelayanan, tentunya mempunyai hambatan dalam membangun komunikasi diantaranya;

a. Sumber daya manusia

Sumberdaya munusia merupakan komponen yang sangat menentukan dalam memberdayakan komunikasi ditengah masyarakat untuk selalu eksis menjalankan program sosialisasi ketika terjun ke masyarakat b. Keterbatasan tenaga yang solid. Tenaga yang solid dalam tim work perlu dalam bekerja karena satiap apa yang dilaksanakan tepat waktu dan sesuai dengan sasaran yang di inginkan.

c. Kepedulian internal. Kepedulian internal sangat mempengaruhi dalam melaksanakan pekerjaan, terutama kesadaran pihak dari public sendiri harus mendukung pelayanan public yang tertib administrasi secara bersama setiap program yang ada.

d. Keterbatasan finansial. Setiap kegiatan sosial identik dengan pengabdi, tanpa mengedepankan keuntungan, sangat mustahil setiap kegiatan tidak membutuhkan finansial atau biaya lain.

\section{a. Pembagian Komunikator}

1. Kepala Ombudsman RI perwakilan Riau. Sebagai leader dalam komunikasi mempunyai peran sebagai komunikator dalam membangun interaksi komunikasi dengan komunikan, sebagai upaya dalam menyampaikan pesan.

2. Lima asisten Ombudsman RI. Sebagai asisten ombudsman dapat berperan sebagai komunikator dalam rangka mensosialisasikan program penyelidikan dan pencegahan.

\section{b. Pesan Komunikasi}

Sebagai pesan dalam komunikasi adalah komunikator melakasanakan program pembinaan untuk melakukan perilaku komunikan adalah terwujudnya pelayanan public yang baik, dapat menerima informasi yang diberikan oleh komunikator.

Proses dalam komunikasi harus mampu menghasilkan pesan dalam hal ini pesan dakwah yang di sampai oleh empat komponen komunikator diatas, karena dianggap sebagai leader yang berpengaruh keberhasilan dari komunikasi tersebut. 
Salah satu unsur dalam membangun wujud dari pencapaian pesan adalah masingmasing individu diatas, sebagai komponen yang mampu memberikan keputusan dari persepsi komunikasi.

\section{c. Media komunikasi}

Salah satu fungsi media adalah sebagai perangkat yang menunjang dari ekspos dan sosialisasi program kepada khalayak komunikasi. Adapun yang menjadi media komunikasi sebagai penyalur pesan dalam mengkomunikasikan aktivitas aduan public diantaranya sebagai berikut: Sebagai media komunikasi, peran media merupakan sebagai wadah untuk membangun komunikasi dengan komunikan seperti Televisi dan Radio serta Media Cetak.

\section{d. Pembagian Komunikan dalam komunikasi}

Komunikan sebagai komponen yang menerima pesan yang disampaikan oleh komunikator untuk mencapai tujuan komunikasi yang diinginkan. Kemudian sebagai chek and balance sebagai keseimbangan dalam pencapaian informasi, peran komunikan ada sebagai user dalam penilaian program tersebut.

Komunikan di tentu kan dalam penilaian tersebut dengan perwakilan secara individu.

\section{e. Feedback sebagai Umpan balik}

Feedback adalah hubungan timbal balik yang dibangun serta dijadikan sebagai penilaian untuk mengukur umpan balik yang diterima oleh komunikan.

Sebagai penilaian komunikasi yang dilaksanakan oleh ombudsman

1. Menurut komunikan yang pertama bahwa komunikasi ombudsman mampu membangun pendampingan pelayanan public.

2. Sebagai komunikan selanjutnya bahwa setiap kegiatan pendampingan dapat dilaksanakan secara berkala karena perannya dapat membantu satuan perangkat kerja daerah yang memiliki predikat rendah.

\section{BAB VI \\ PENUTUP}

\section{a. Kesimpulan}

Komunikasi ombudsman sebagai lembaga pengawasan public pada lembaga pemerintah sangat berperan penting bagi public atau masyarakat yang konsumen pelayanan di lembaga pemerintah dalam memberikan pelayanan yang baik, bahwa ombudsman dapat meningkatkan feedback pelayanan antara pemerintah dan masyarakat.

Dari hasil komunikasi Ombudsman dapat memberikan pemahaman kepada public dengan mensosialisasikan kepada khalayak atau masyakat sebagai lembaga resmi yang mampu melakukan mediasi pelayanan public yang baik pada lembaga pemerintah. Setiap satuan kerja yang ada dikabupaten kota di Provinsi Riau, ombudsman memberikan sosialisasi untuk meningkatkan pelayanan public yang baik, berupa pelayanan prima kepada masyakat sesuai dengan moto kerja bagi setiap birokrat pada lembaga pemerintah. Sebagai tahapan pengawasan yang dilakukan ombudsman ada dua tahap yaitu;pertama, penyelidikan lapangan dan yang kedua pencegahan.

\section{b. Saran}

1. Komunikasi ombudsman dalam mensosialisasikan pengawasan aduan public dapat memberikan kontribusi bagi setiap SKPD di Provisi Riau.

2. Setiap satuan kerja perangakat daerah dapat terpantau kerjanya oleh 
Ombudsman dan dapat dievalusi terhadap mutu layanan public.

3. Masyarakat mendapat pelindungan terhadap pelayanan public yang diberikan oleh pemerintah.

\section{DAFTAR KEPUSTAKAAN}

Arifin Anwar, Ilmu Komunikasi, Jakarta, Raja Wali Grafindo Persada

Bungin Burhan Muhammad. 2008. Penelitian Kualitatif; Komunikasi, Ekonomi, Kebijakan Public, dan Ilmu Sosial lainnya, Jakarta, Kencana Prenada Group

Coulson Colin dan Thomas. 2005. Public Relation, Pedoman Praktis Untuk PR Jakarta, Bumi Aksara.

Liliweri, Sosiologi Organisasi, Bandung, Citra Aditya Bakti

Mulyana Deddy, Nuansa-Nuansa Komunikasi, Meneropong Politik dan Budaya Komunikasi Masyarakat Kotemporer, Bandung, Remaja Rosdakarya

Nurudin, Komunikasi Propaganda, Bandung, Remaja Rosdakarya.

Ombudsman Republic Indonesia. 2014. Untuk Para Pengabdi, Jakarta.

Olii Helena dan Erlta Novi.2011. Opini Public, Jakarta, PT Indeks

Ruslan Rosady.2006. Kiat dan Strategi Kampanye Public Relations. Jakarta, Raja Grafindo persada

Siagian Sondang P. 2008. Manajemen Sumber daya Manusia, Jakarta, Bumi Aksara.

Tangkilisan Hessel Nogi S. 2003. Kebijakan Public Untuk Pemimpin Berwawasan Internasional, Yogyakarta, Balairung dan Co.Undang-Undang Republik Indonesia, nomor 37 tahun 2008 tentang Ombudsman dan UU nomor 25 tahun 2009, Tentang Pelayanan Public.

Walid M. Ramli. 2008. Mewujudkan Good Governance Di Provinsi Riau, Pekanbaru, Alaf Riau.

West Richard dan Turner Lynn H, Pengantar Teori Komunikasi Analisis dan Aplikasi Introducing Communication Theory, Jakarta, Salemba Humanika,

R. Zuhro Siti dkk. 2009. Demokrasi Lokal, Yogyakarta, Ombak. 
